\title{
Pnömatik Sistemlerde Enerji Verimliliği
}

\author{
Arda Zaim*1 \\ Haydar Aras ${ }^{2}$
}

\section{ÖZ}

Artan nüfus ve gelişen teknolojiyle birlikte enerji tüketimi ve maliyetleri günden güne artış göstermektedir. Ülkemiz fosil enerji kaynakları bakımından sınırlı kaynaklara sahip ve dışa bağımlıdır. Enerji ihtiyacının güvenilir, ekonomik ve yeterli bir biçimde karşılanabilmesi temel amaçtır. Bu bağlamda enerjinin verimli kullanımı üzerinde önemle durulması gereken hususlar arasında yer almaktadır. Enerji verimliliği, harcanan enerji miktarının, üretimdeki kapasite ve kaliteyi azaltmadan, ekonomik kalkınmayı ve sosyal refahı engellemeden en aza indirilmesidir. Bu çalışmada, endüstride en çok kullanılan ikincil enerji kaynağı basınçlı havayla çalışan pnömatik sistemlerdeki enerji verimliliği uygulamaları ele alınmış ve deneysel çalışmalarla desteklenmiştir. Basınçlı hava sistemi tasarımında verimliliği artıran unsurlar belirlenmiş; kompresör, silindir ve vakum ejektörü gibi pnömatik iş elemanlarında işletme basınçlarının düşürülmesiyle elde edilebilecek tasarruf miktarları hesaplanmıştır. Ciddi maliyetler oluşturan hava kaçaklarının tespiti ve maliyeti konusunda fiziki bulgular incelenmiş, enerji tasarruf fonksiyonlu ürünlerin kullanımı için yol gösterilmiştir. Çalışmanın, enerji arzında büyük oranda dışa bağımlı olan ülkemizin sanayi sektöründe enerji yoğunluğunun düşürülmesi ve karbon ayak izinin azaltılması faaliyetlerinde bir rehber niteliği taşıyacağı düşünülmektedir.

Anahtar Kelimeler: Basınçlı hava, enerji verimliliği, enerji yoğunluğu, pnömatik

\section{Energy Efficiency in Pneumatic Systems}

\begin{abstract}
With increasing population and developing technology, energy consumption and costs are increasing day by day. Our country has limited resources in terms of fossil energy sources and is dependent on foreign sources. The main objective is to meet the energy needs reliably, economically and adequately. In this context, efficient use of energy is important. Energy efficiency is the minimization of the amount of energy spent, without reducing the capacity and quality of production, preventing economic development and social welfare. In this study, energy efficiency applications in compressed air pneumatic systems are discussed. The elements that increase efficiency in the design of the compressed air system were determined; savings that can be achieved by reducing operation pressures in pneumatic equipments such as compressor, cylinder and vacuum ejector have been calculated. Physical findings about the detection and cost of leakages that cause serious costs were examined and a way was provided for the use of products with energy saving functions. It is considered that the study will be a guide in the activities of reducing the energy density and the carbon footprint of our country, which is highly dependent on foreign energy.
\end{abstract}

Keywords: Compressed air, energy efficiency, energy density, pneumatic

\footnotetext{
* İletişim Yazarı

Geliş/Received : $\quad$ 17.09.2019

Kabul/Accepted : 20.03 .2020

1 Makine Yüksek Mühendisi, FESTO Sanayi ve Ticaret A.Ş. Tuzla, İstanbul - arda.zaim@festo.com ORCID: 0000-0002-2602-3169

2 Prof. Dr., Eskişehir Osmangazi Üniversitesi - haras@ogu.edu.tr ORCID: 0000-0001-8131-6426
} 


\section{GÍRİş}

Artan nüfus ve gelişen teknolojiyle birlikte enerji tüketimi ve maliyetleri günden güne artı̧̧ göstermektedir. Ülkemizde 2018 yılında 303.3 TWh elektrik tüketimi ve 303.9 TWh elektrik üretimi gerçekleşmiştir. Elektrik üretimimizin \%67,1'i kömür ve doğal gaz gibi fosil kaynaklardan, geri kalan \%32,9'u ise yenilebilir enerji kaynakları olan hidrolik, rüzgar, güneş ve jeotermal enerjiden elde edilmiştir. Şekil 1'de gösterildiği gibi TEİAŞ 10 y1llık talep tahminleri raporuna göre 2027 yılında ülkemizdeki elektrik tüketiminin 2018 yılına kıyasla \%50.4 artarak brüt 457.9 TWh olması beklenmektedir [1].

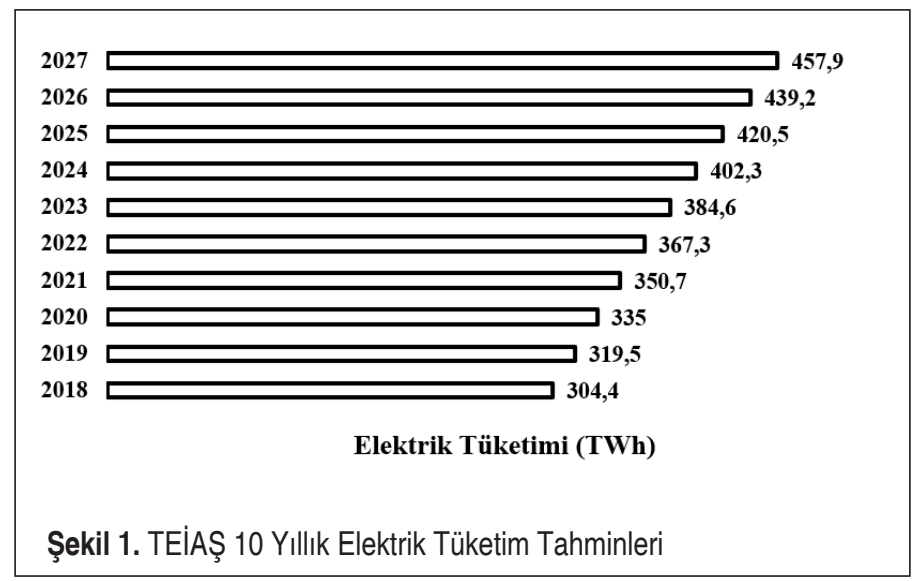

Elektrik üretimi için büyük oranda fosil enerji kaynaklarını kullanan ülkemiz fosil enerji kaynakları bakımından sınırlı ve dışa bağımlıdır. Şekil 2'de görüldüğü üzere Türkiye'nin toplam enerji arzında dışa bağımlılığı 1990 yılında \%52 iken 2000 yılında $\% 67,2010$ 'da $\% 70$ ve 2016 yılında \%74'e ulaşarak son yirmi altı yılda \%22 artış göstermiştir [2].

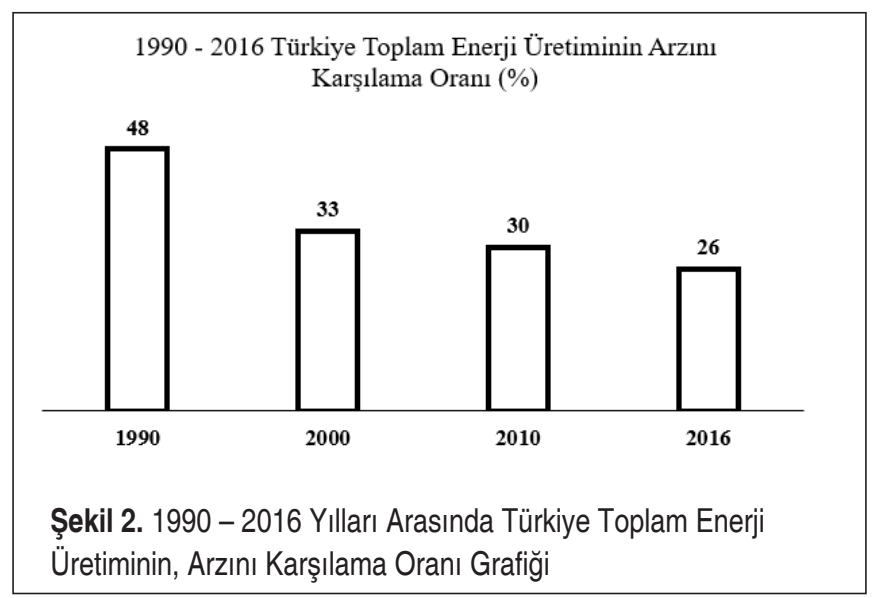


Enerji ihtiyacının güvenilir, ekonomik ve yeterli bir biçimde karşılanabilmesi temel amaçtır. Enerji verimliliği, harcanan enerji miktarının, üretimdeki kapasite ve kaliteyi azaltmadan, ekonomik kalkınmayı ve sosyal refahı engellemeden en aza indirilmesidir [3]. Enerji üretiminin, arzı karşılama oranında dışa bağımlılı̆̆ı artan ülkemizde, enerjinin verimli kullanımı üzerinde önemle durulması gereken konular arasında yer almaktadır. Enerji verimliliği ve tasarrufu, enerji arz güvenliğinin sağlanması, dışa bağımlılık risklerinini azaltılması, çevrenin korunması ve iklim değişikliğine karşı mücadelenin etkinliğinin artırılmasının sağlanması konusularında önemli bir araçtır [4].

Enerji verimliliği tüm sektörler için önemli olmasına rağmen, önümüzdeki yılların enerji tüketimi ve sektörün enerji yoğunluğu açısından sanayi sektörü önceliklidir. Enerji yoğunluğu, Gayri Safi Milli Hasıla başına tüketilen birincil enerji miktarını temsil eden ve tüm dünyada kullanılan bir göstergedir. Bu gösterge içinde, ekonomik çıktı, enerji verimliliğindeki artış ve azalma, yakıt ikameside değişimler birlikte ifade edilmektedir. Enerji yoğunluğu; herhangi bir fiziksel ya da teknik göstergenin (enerji tüketimi, spesifik enerji tüketimi vb.) herhangi bir faaliyetin verimlilik düzeyini açıklayamadığı durumlarda bir enerji verimliliği göstergesi olarak kullanılmaktadır. Sanayi sektöründe enerji yoğunluğunun düşürülmesi ülkemizdeki enerji yoğunluğunun düşürülmesinde büyük bir etkiye sahip olacaktır [5].

Enerji İşleri Genel Müdürlüğü’nün 2000 - 2017 yılları arası için hazırlamış olduğu enerji yoğunluğu indeksi Şekil 3'de gösterilmektedir. Ülkemizde 2000 - 2017 dö-

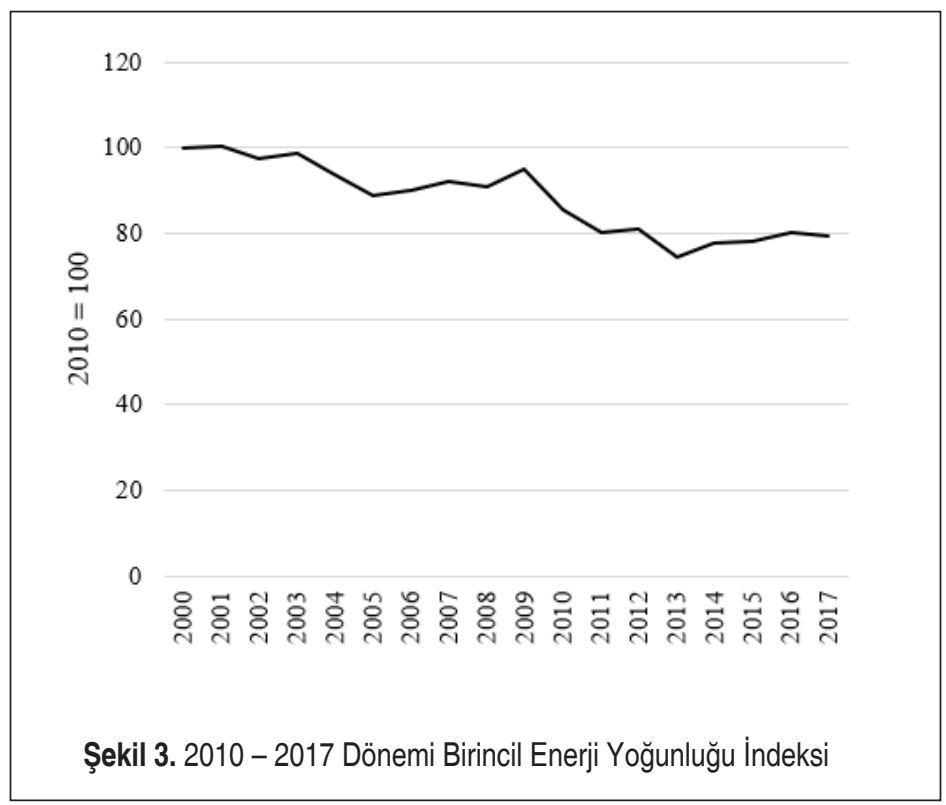


neminde birincil enerji yoğunluğu indeksi ortalama \%1.3 oranında azalmıştır. 2000 yılına göre bir karşılaştırma yapıldığında ise 2017 yılında birincil enerji yoğunluğu indeksinde \%20.5 iyileşme söz konusudur. 02.01.2018 tarihinde yürürlüğe giren, ülkemizin ilk enerji verimliliği eylem planı olan Ulusal Enerji Verimliliği Eylem Planı kapsamında 2023 yılına kadar yapılacak olan tasarruf eylemleriyle birincil enerji yoğunluğunda 2017 yılına kıyasla \%14 oranında bir azalma hedeflenmektedir [6].

Karbon ayak izi her insanın ulaşım, ısınma, enerji tüketimi veya satın aldığı her türlü ürün neticesinde atmosfere yayılmasına neden olduğu karbon miktarını anlatmak üzere kullanılan bir terimdir. Başka bir deyişle, gerçekleştirdiğimiz her faaliyet için gereki olan enerjinin üretilmesi sırasında atmosfere salınan karbon gazı toplamını ifade etmektedir [7]. Karbon ayak izi özellikle fosil yakıtlardan elde edilen enerjiye dayalı bir tanım olduğu için karbon ayak izinin azaltılması aynı zamanda enerji tüketiminin azaltılması veya optimizasyonu anlamına gelmektedir. Ülkemizde enerji ihtiyacının büyük oranda fosil kaynaklardan sağlandığı ve endüstride kullanılan basınçlı havanın elektrik enerjisiyle üretildiği göz önünde bulundurulduğunda pnömatik sistemlerdeki enerjinin verimli kullanımıyla karbon ayak izinde ciddi bir azalma meydana gelecek$\operatorname{tir}[8]$.

Endüstride en çok kullanılan ikincil enerji kaynağı basınçlı havadır. Basınçlı havayı enerji kaynağı olarak kullanılan makine ve ekipmanlar pnömatik sistemler olarak tanımlanmaktadır. Pnömatik sistemlerde enerji verimliliği ise, pnömatik iş elemanlarında kullanılan havanın gerektiği kadar basınçlandırılması, şartlandırılması ve tüketilmesi esasına dayanmaktadır. Bu çalışmada basınçlı havayla çalışan pnömatik sistemlerdeki enerji verimliliği uygulamaları ele alınmış ve deneysel çalışmalarla desteklenmiştir. Çalışma basınçlı havanın verimli kullanımıyla enerji yoğunluğunun düşürülmesini ve karbon ayak izinin azaltılmasını amaçlamaktadır.

\section{BASINÇLI HAVA ÜRETIMI, ŞARTLANDIRILMASI VE ILETIMINDE TASARRUF OLANAKLARI}

Basınçlı hava dış ortamdan alınan atmosfer havasının bir kompresör ile belirli bir oranda sıkıştırılması ile elde edilmektedir. Elektrik enerjisinin olduğu her yerde elde edilebilen ve depolanabilir olması nedeniyle endüstride en çok tercih edilen enerji kaynaklarından birisidir. Basınçlı hava kolay elde edilip yaygın bir kullanıma sahip olmasına karşın oldukça pahalı bir enerji türüdür. Basınçlı hava kullanımı ve kompresörlerin enerji tüketimi verimlilik çalışmalarında dikkat edilmesi gereken unsurlar arasındadir [9].

Şekil 4'de örnek bir işletmedeki basınçlı hava üretimi, dağıtımı ve kullanımı gösterilmektedir. Burada hava kompresör tarafından sıkıştırılarak basınçlandırılmakta, tankta depo edilmekte, kurutucu tarafından soğutularak neminden arındırılmakta ve filtrelenerek işletmeye servis edilmektedir. Kompresörler; güneş 1şığından ve 1sı kaynakla- 
rından uzak, sıcaklığın ve tozun az olduğu ortamlarda konuşlandırılmalıdır. Soğuk, temiz ve kuru hava prensip olarak verimli bir sıkıştırma sağlamaktadır. Kompresör emiş havası sıcaklığının her 5 oC düşürülmesiyle, verim $\% 2$ artış göstermektedir. $\mathrm{Bu}$ nedenle kompresör daireleri için binaların kuzey yönünde ve yağmurdan korunak11 bir konum tercih edilmelidir. Kompresörlerin eksoz havaları, bulunduğu ortamın sıcaklığını artırmayacak şekilde atmosfere verilmelidir. En düşük spesifik enerji ve yüksüz enerji tüketimine sahip kompresör seçimiyle elektrik enerjisi tüketimi ve işletme maliyetleri önemli ölçüde azaltılabilmektedir. Spesifik enerji tüketimini etkileyen diğer bir önemli husus ise periyodik bakımdır. Kompresörlerin verimli kullanılmasını sağlamak amacıyla periyodik bakımlar düzenli olarak yapılmalıdır [10,11].

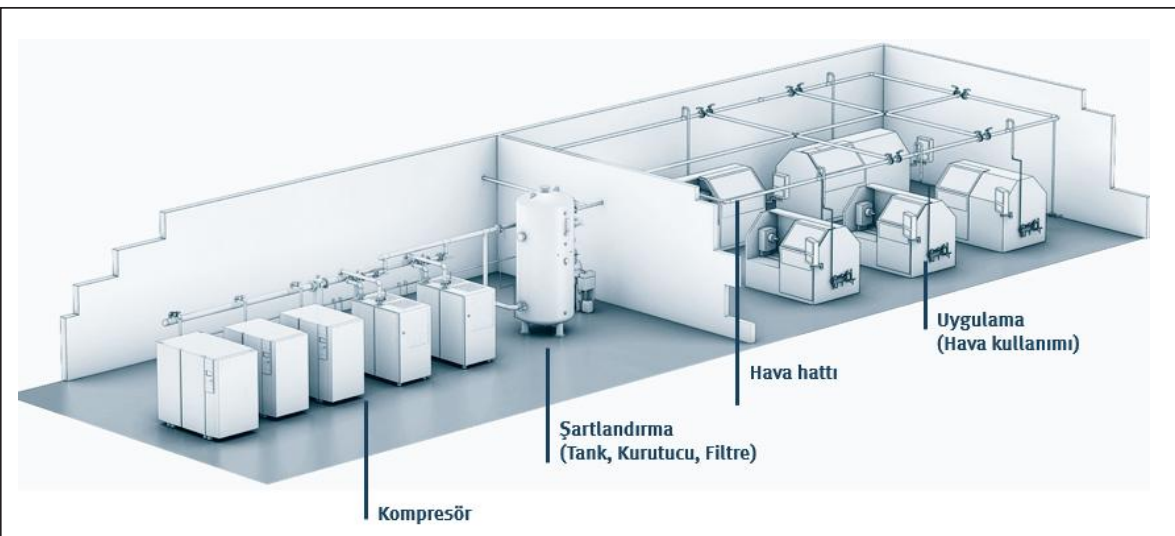

Şekil 4. İşletmede Basınçlı Hava Üretimi ve Kullanımı

Kompresör işletme basıncı mümkün olduğunca düşük tutulmalıdır. Yüksek basınç, yüksek enerji tüketimi ve maliyet demektedir. Yüksek basınç istenen muhtelif noktalardaki cihaz ve makinelerin işletilebilmesi için ana sistem basıncının yükseltilmesi yerine, basınç lokal olarak basınç yükselticiler kullanılarak servis edilmelidir. Tablo 1 'de kompresör işletme basıncının düşürülmesiyle elde edilebilecek tasarruf oranları gösterilmektedir [12].

Basınçlı hava hatları tasarlanırken basınç kaybını minimize etmek için mümkün olduğunca keskin dönüşlerden kaçınılmalı, boru çapları doğru tayin edilmeli, hatta yoğuşan suyun ve yağ zerreciklerinin kolay ayrıştırılabilmesi için drenaj noktaları oluşturulmalı, ana hattan oluşturulan tali hatların deve boynu tekniğiyle oluşturulması ve hattın \%1 oranında eğimli olmasına dikkat edilmelidir. Sabit boru şebekelerinde kompresörden çıkan havanın hattın sonuna kadar toplam basınç düşüşü 0,5 bardan fazla olmamalıdır. Basınç düşüşünün önüne geçmek amacıyla ring metodu benimsenerek tasarım yapılmalıdır [13]. 
Tablo 1. İşletme Basıncının Düşürülmesiyle Elde Edilebilecek Tasarruf

\begin{tabular}{|c|c|}
\hline Basınç Düșüșü (bar) & Tasarruf (\%) \\
\hline $12-11$ & 8 \\
\hline $11-10$ & 8 \\
\hline $10-9$ & 9 \\
\hline $9-8$ & 10 \\
\hline $8-7$ & 11 \\
\hline $7-6$ & 12 \\
\hline $6-5$ & 14 \\
\hline $5-4$ & 17 \\
\hline $4-3$ & 20 \\
\hline
\end{tabular}

Kurutucu seçimi yapılırken kompresörün sahip olduğu üretim kapasitesi dikkate alınmalıdır. Halihazırda yürürlükte olan ISO 8573-1:2010 basınçlı havada kalite standartı göz ününde bulundurularak işletmede kullanılması gereken hava kalite sınıfı tespit edilmeli, hava gerektiği kadar şartlandırılmalıdır. Gereğinden fazla yapılan şartlandırma işleminde basınç ve debi kayıpları meydana gelecek, bu durum maliyetin artmasına neden olacaktır. Filtreleme işlemi düşük hassasiyetten yüksek hassasiyete doğru yapılmalıdır. Şekil 5'de gösterilen şartlandırıcı ünitelerinde kullanılan filtre kartuşlarının periyodik olarak değiştirilmesine dikkat edilmelidir. Sinter filtrelerin temizlenebilme özelliği yoktur, bu nedenle kirlenen filtreler mutlaka değiştirilmelidir. Aksi taktirde filtre olması gerekenden fazla basınç kaybına neden olarak hava maliyetini artıracaktır. Pratik olarak fark basıncı metoduyla işletme özel periyodik bakım aralıkları belirlenmelidir.

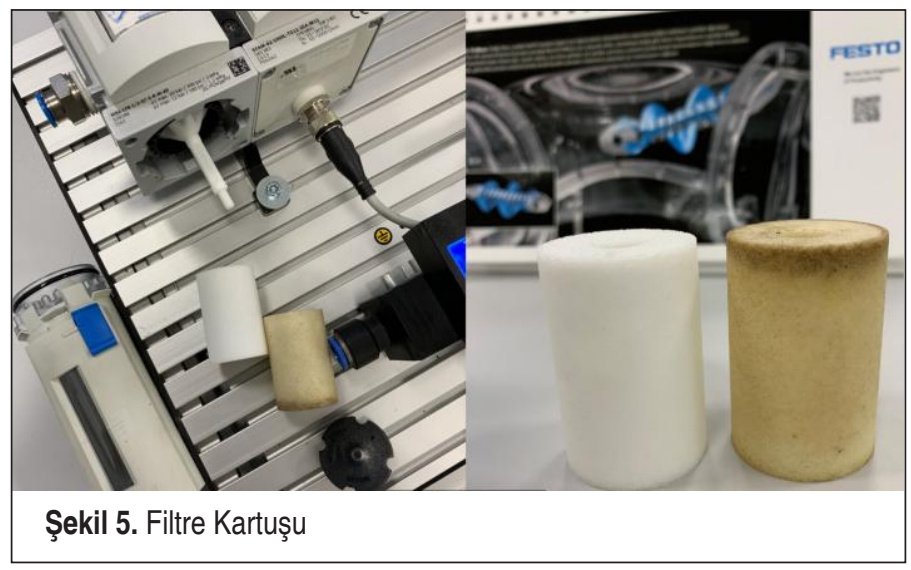




\section{PNÖMATIKK EKIPMANLARDA ENERJİ VERIMLILIIĞİ UYGULAMALARI}

Pnömatik iş elemanlarında doğru ürün seçimiyle tasarruf elde etmek mümkündür. Tasarım safhasında pnömatik iş elemanları, mevcut uygulamaya göre itme kuvvetleri göz önünde bulundurularak optimum şekilde seçilmelidir. Tablo 2'de $200 \mathrm{~mm}$ strok boyuna sahip ISO 15552 pnömatik silindir çaplarının bir alt kademeye düşürülmesiyle elde edilebilecek tassaruf miktarları gösterilmektedir.

Tablo 2. Çap Düşürülmesiyle Elde

Edilebilecek Enerji Tasarrufu

\begin{tabular}{|c|c|}
\hline Çap Düșüșü (mm) & Tasarruf (\%) \\
\hline $125-100$ & 34 \\
\hline $100-80$ & 36 \\
\hline $80-63$ & 37 \\
\hline $63-50$ & 36 \\
\hline $50-40$ & 37 \\
\hline $40-32$ & 32 \\
\hline
\end{tabular}

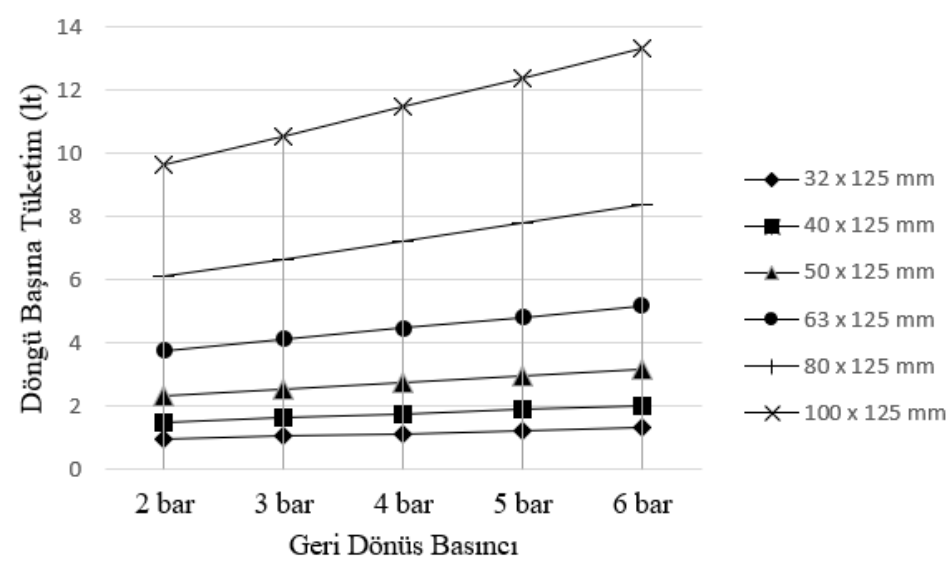

Şekil 6. Farkı Çap ve Geri Dönüş Basınçları İçin Hava Tüketimi Grafiği

Pnömatik iş elemanlarında mekanik bir değişiklik yapmadan da enerji tasarrufu sağlanabilmektedir. Tek yönlü iş yapan (itme ya da çekme yönünde) çift etkili (ileri ve geri hareketini havayla gerçekleştiren) pnömatik iş elemanlarında geri dönüş basınc1nın prosesi etkilemeyecek derecede düşürülmesiyle hava tüketimi azaltılabilmektedir. 
Şekil 6'da 125 mm strok boyuna sahip ISO 15552 pnömatik silindirlerin geri dönüş basıncının düşürülmesiyle elde edilebilecek tasarruf miktarları gösterilmektedir.

Endüstride basınçlı havayı kullanan önemli elemanlardan biri de vakum ejektörüdür. Vakum ejektörü enerji kaynağı olarak basınçlı havayı kullanarak vakum elde eden cihazlardır. Vakum ejektörü, herhangi bir hareketli parça olmadan pnömatik olarak venturi prensibiyle vakum üretmektedir. Kompakt yapısı ve ilk yatırım maliyetinin düşük olması nedeniyle endüstriyel taşıma uygulamalarında kendine önemli bir yer edinmiştir. İlk yatırım maliyetinin düşük olmasına karşın bu cihazların işletme maliyetleri ciddi derecede yüksektir [14]. Venturi prensibine göre çalışan $1.4 \mathrm{~mm}$ orifis çapına sahip bir vakum ejektörünün optimum çalışma koşullarını belirlemek amacıyla Şekil 7'de gösterilen deney düzeneği oluşturulmuştur. Farklı basınç ve debi değerlerinde vakum ejektörünün hava tüketimi, vakum basıncı ve vakum debisi değerleri belirlenmiştir.

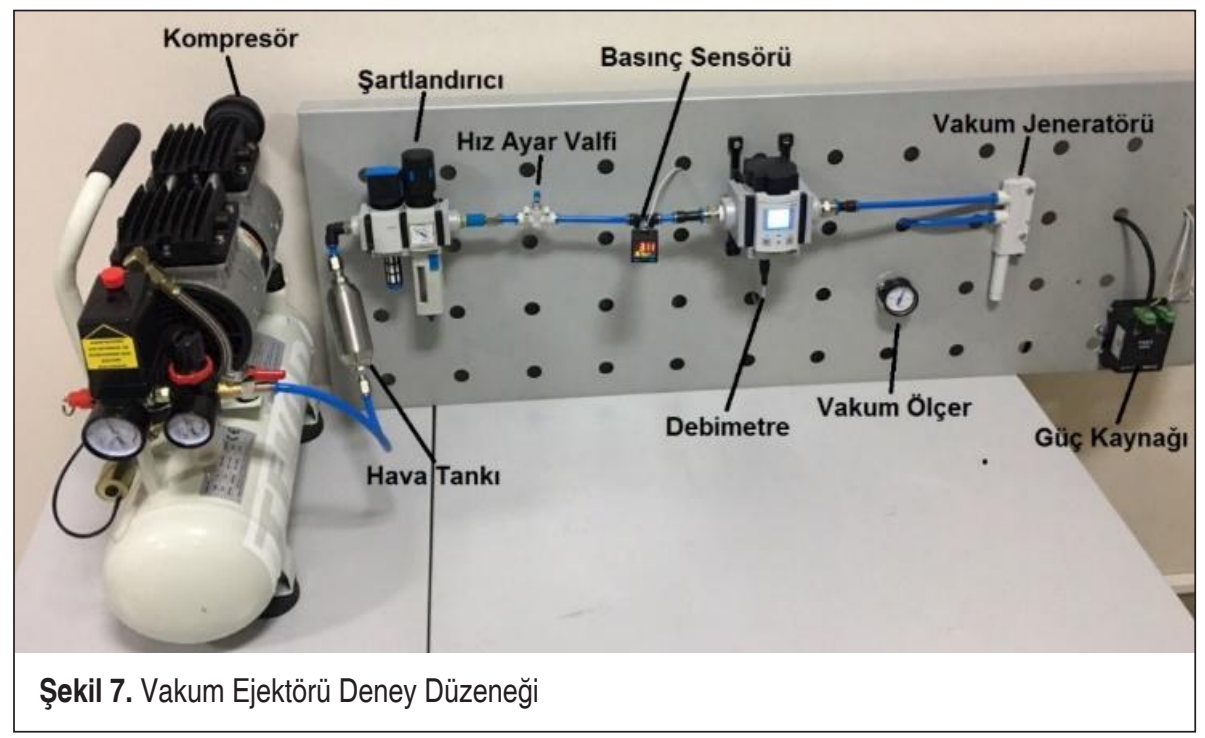

Şekil 8'de görüleceği gibi 1.4 mm orifis çapına sahip venturi prensibiyle çalışan pnömatik ejektöründe elde edilebilecek maksimum vakum basıncı, 5,0 bar basınçlı hava beslemesiyle oluşmaktadır. Bu tip vakum ejektörlerinin kritik işletme basıncının üzerinde bir basınçla işletilmesi enerjinin verimsiz kullanımına örnek teşkil edecektir. Verim düşecek, birim başına harcanan enerji miktarı artış gösterecektir. Maksimum vakum debisi değeri olan 51,2 lt/dk'ya 5,0 bar basınç ve 94 lt/dk işletme debisi parametrelerinde ulaşılmaktadır. Bu noktadan sonra işletme debisi artarken vakum debisi değerinde azalış gözlenmektedir. Maksimum vakum basıncı grafiğinde olduğu 
gibi, vakum debisi için de kritik basınç değeri 5,0 bar'dır. Vakum ejektörünün kritik işletme basıncının üzerinde çalıştırılması performans kaybına ve enerji tüketiminin artışına neden olmaktadır.

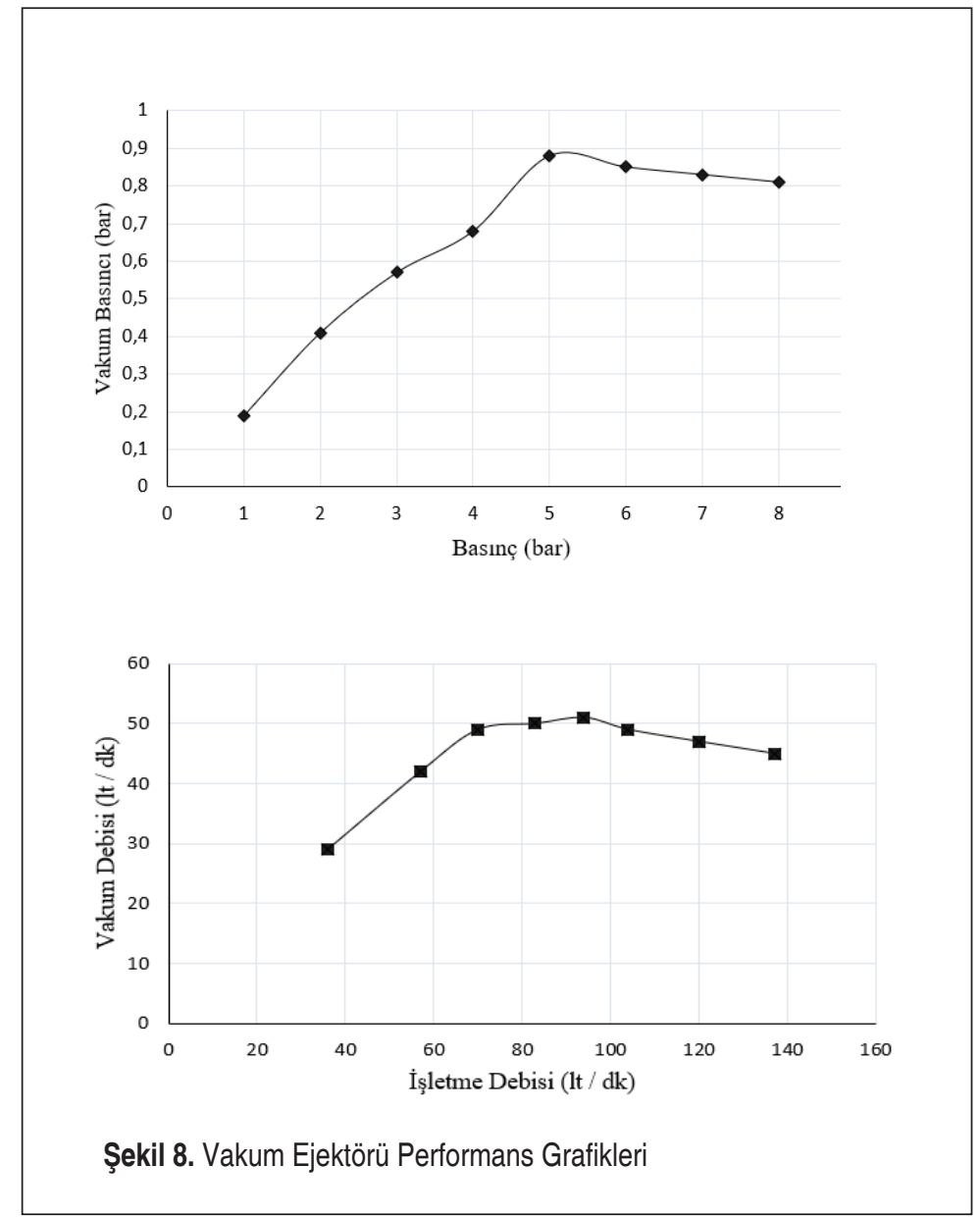

Şekil 9'da hacimsel verim ve vakum basıncı değerlerinin, işletme basıncıyla olan ilişkisi gösterilmektedir. Vakum ejektörünün hacimsel verimi, elde edilen vakum debisi değerinin hava tüketimine oranlanması ile hesaplanmaktadır. 1,0 bar işletme basıncında \%80,5 olan hacimsel verim, 8,0 bar işletme basıncında \%32,8'e kadar düşmektedir. 3,7 bar işletme basıncında hacimsel verim ve vakum basıncı eğrileri kesişmektedir. Optimum nokta olarak tanımlanabilecek bu noktada hacimsel verim ve vakum değeri \%64,7'dir. Enerji tüketimi açısından irdelendiğinde 3,7 bar işletme basıncında hava tüketimi 79,1 lt/dk, vakum debisi 49,7 lt/dk ve vakum basıncı -0,647 bar olarak ölçülmektedir. 


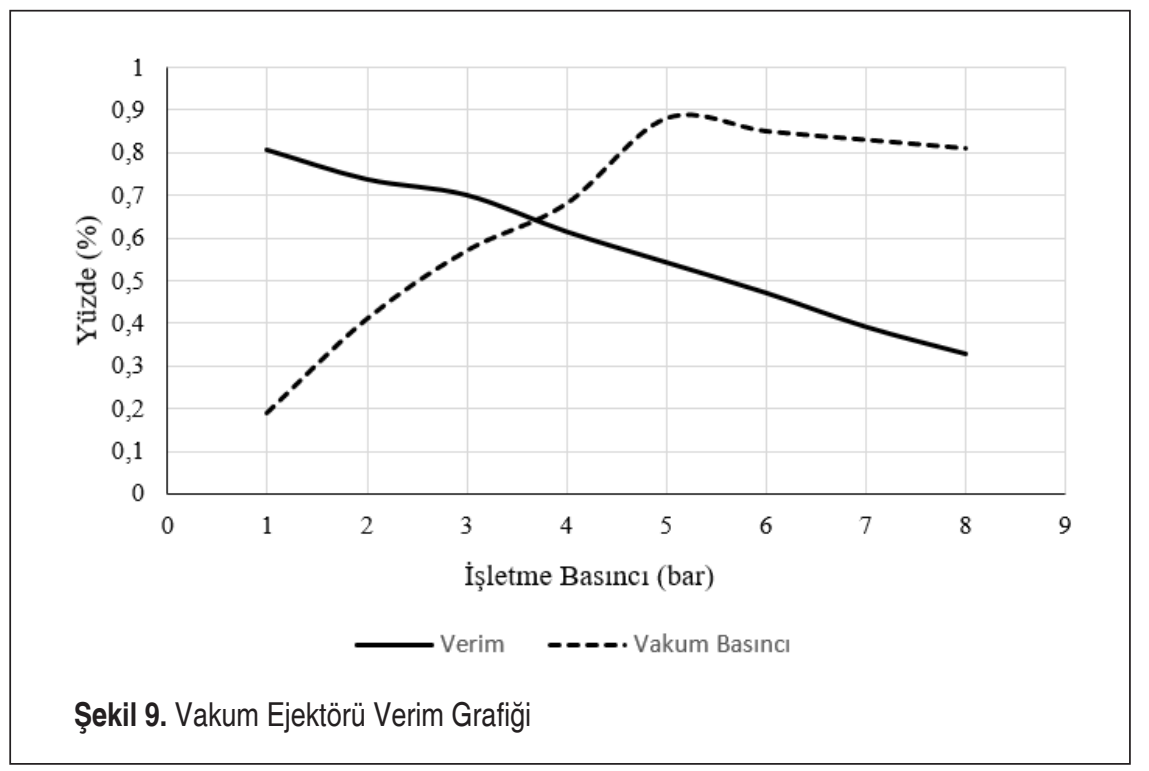

Pnömatik vakum ejektörü performansı ve enerji verimliliği açısından durum değerlendirildiğinde, maksimum vakum basıncı ve vakum debisi değerlerine ulaşılan işletme basıncı 5,0 bar, optimum noktadaki işletme basınc 3,7 bar olarak tespit edilmiştir. Belirtilen işletme basıncı değerleri için hava tüketimi miktarları Tablo 3'de gösterilmektedir. Vakum ejektörünün yılda 3000 saat çalıştığı öngörüldüğünde; sirasıyla 3,7, 5,0 ve 7,0 bar işletme basınçlarında yıllık hava tüketimleri $14238 \mathrm{~m}^{3}, 16920 \mathrm{~m}^{3}$ ve $21636 \mathrm{~m}^{3}$ olmaktadır. İşletme basıncı 7,0 bar'dan kritik basınç olan 5,0 bar'a düşürüldüğünde $\% 21,8,7.0$ bar'dan ekonomik basınç olan 3,7 bar'a düşürüldüğünde ise $\% 34,2$ oranında tasarruf sağlanabilmektedir.

Tablo 3. Farkıı İşletme Basınçları İçin Hava Tüketimleri

\begin{tabular}{|c|c|c|}
\hline İşletme Basıncı (bar) & Hava Tüketimi (It/dk) & 3000 Saatlik Hava Tüketimi $\left(\mathrm{m}^{3}\right)$ \\
\hline 3,70 & 79,1 & 14238 \\
\hline 5,00 & 94,0 & 16920 \\
\hline 7,00 & 120,2 & 21636 \\
\hline
\end{tabular}

Pnömatik sistemlerde enerji verimliliğini etkileyen diğer bir önemli unsur ise hava kaçaklarıdır. Birçok endüstriyel tesiste önemsiz olarak nitelendirilen kaçaklar ciddi bir maliyet oluşturmaktadır. Bu kaçakların bir kısmı insan kulağının duyabileceği frekansta olup, bir kısmı ise ultrasonik detektörler tarafindan tespit edilebilmektedir. Tablo 4'de farklı basınçlarda belirli bir çaptan geçebilecek hava debisi değerleri gösterilmektedir. 
Tablo 4. Farkı Basınçlarda Belirli Bir Çaptan Geçebilecek Hava Debisi

\begin{tabular}{|c|c|c|c|c|c|}
\hline \multicolumn{6}{|c|}{ Farklı basınçlarda belirli bir çaptan geçebilecek hava debisi (It/dk) } \\
\hline Çap & $0.5 \mathrm{~mm}$ & $1 \mathrm{~mm}$ & $1.5 \mathrm{~mm}$ & $2.0 \mathrm{~mm}$ & $2.5 \mathrm{~mm}$ \\
\hline 4 bar & 9 & 36 & 81 & 145 & 226 \\
\hline 5 bar & 11 & 45 & 102 & 181 & 282 \\
\hline 6 bar & 14 & 54 & 122 & 217 & 339 \\
\hline 7 bar & 18 & 72 & 163 & 289 & 452 \\
\hline
\end{tabular}

Hava kaçakları mekanik hasarların yanı sıra özellikle bağlantı elemanları ile hortumlar arasındaki tolerans farklılıkları nedeniyle meydana gelmektedir. İşletmelerde basınçlı havanın verimli kullanımını sağlamak amacıyla kaçak seviyesi en aza indirgenmeli, Şekil 10'da gösterildiği gibi ultrasonik dedektörlerle periyodik olarak kaçak tespit uygulamaları gerçekleştirilmelidir.

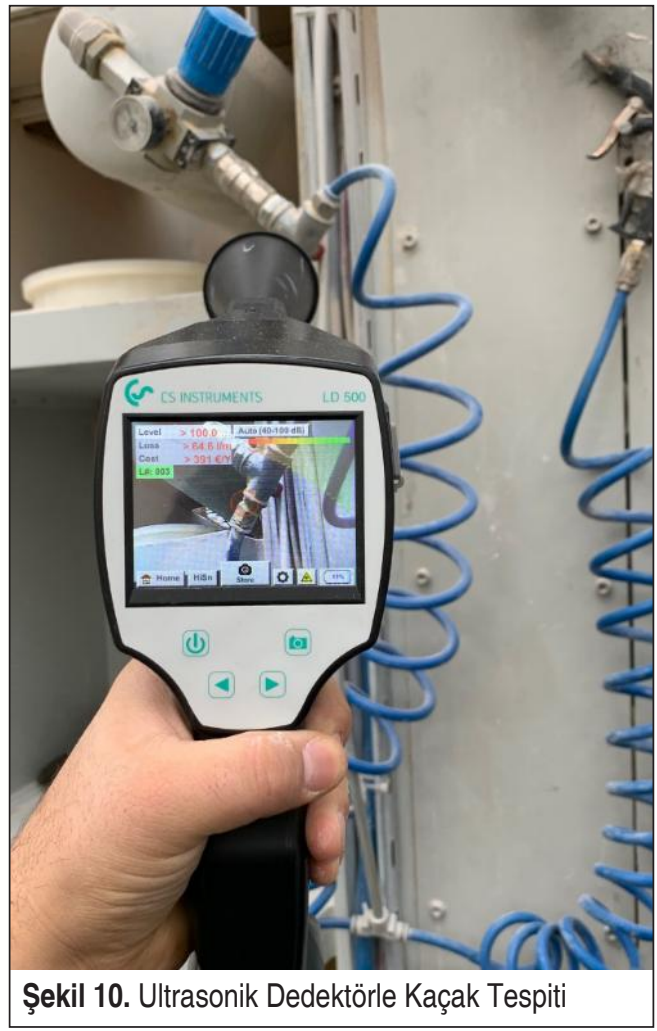


Endüstride üretim proseslerinde birçok sektörde açık üfleme uygulamaları yaygın olarak tercih edilmektedir. Açık üflemeler kurutma, soğutma ve temizleme gibi işlemler için kullanılmaktadır. Bu işlemlerde tüketilen hava miktarı oldukça fazladır. Enerji verimliliği açısından açık üfleme uygulamaları için ürün ve proses kalitesinden ödün vermeden fan havası üflemeleri sistemlere entegre edilmelidir. Hava tabancası kullanımında enerji tasarruf fonksiyonu olan ürünlerin kullanımına öncelik verilmelidir. Şekil 11'de görüleceği üzere enerji tasarruf fonksiyonlu hava tabancaları tercih ederek \%60'lara varan tasarruf sağlamak mümkün olmaktadır.

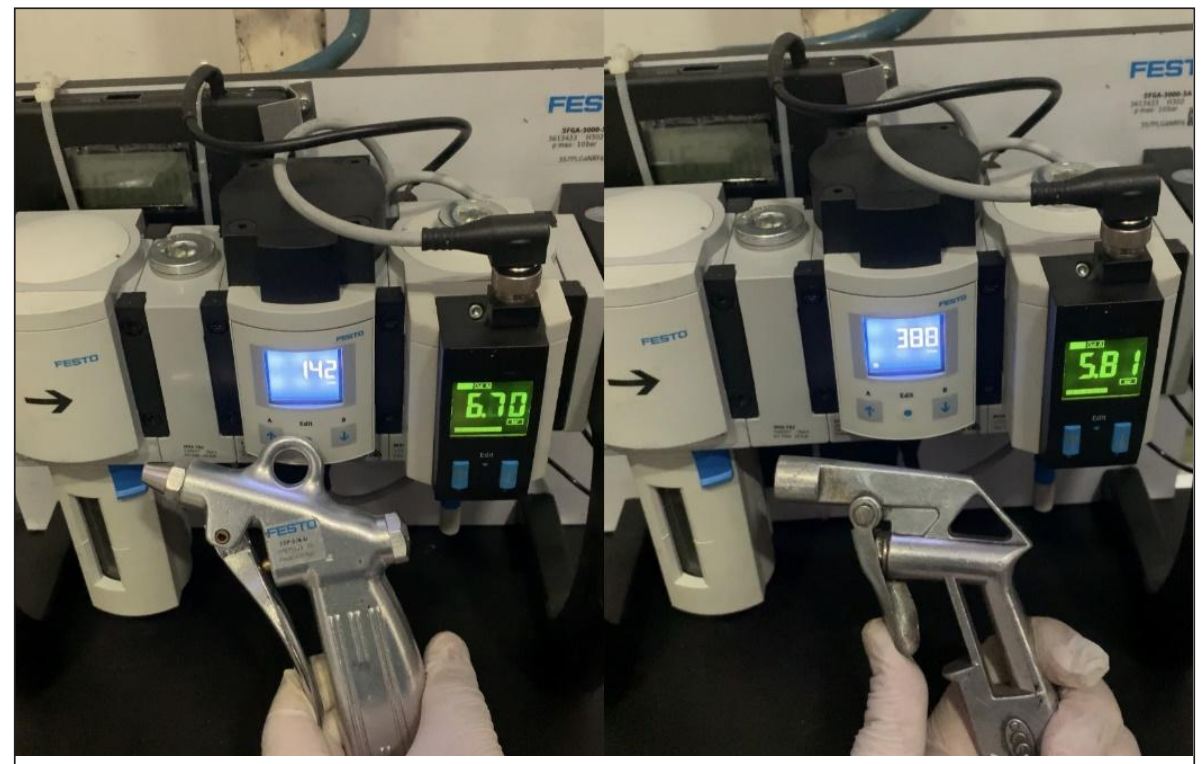

Şekil 11. Hava Tabancası Tüketim Karşılaştırması

Enerji verimliliğinin temeli harcanan enerji miktarının üretimdeki kapasiteyi ve kaliteyi azaltmadan en aza indirilmesidir. Verimlilik konusunda yorum yapabilmek için üretilen ve tüketilen hava miktarlarının bilinmesi gereklidir. Şekil 12'deki gibi debimetreler kullanılarak hava tüketimleri sürekli olarak takip edilmelidir. Basınçlı havanın verimli kullanımını artırmak amacıyla bu ölçümler makine bazına indirgenmeli, debimetre cihazlarının kullanımı yaygınlaştırılmalıdır. 


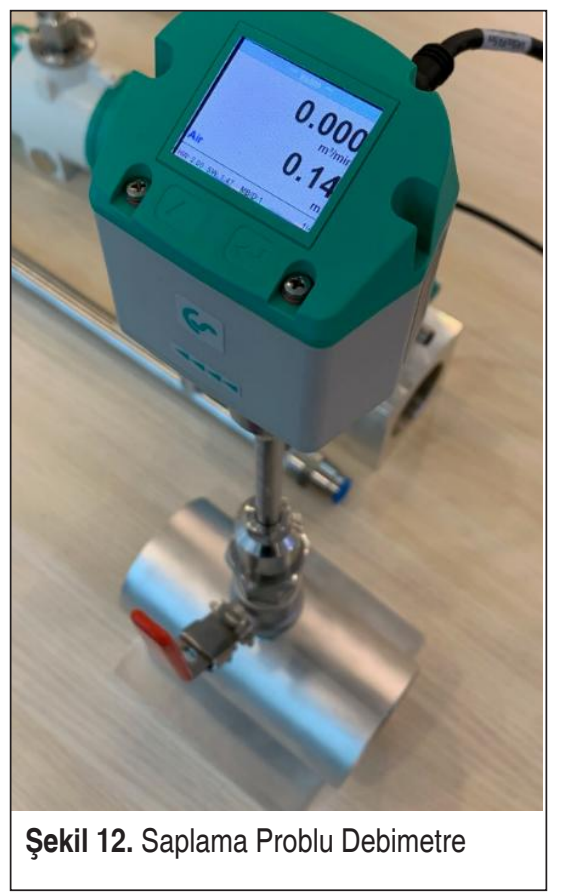

\section{SONUÇ VE ÖNERILER}

$\mathrm{Bu}$ çalışmada, endüstride en çok kullanılan enerji kaynaklarından birisi olan basınçlı havayla çalışan pnömatik sistemlerdeki enerji verimliliği uygulamaları ele alınmış ve deneysel çalışmalarla desteklenmiştir. Basınçlı havanın elde edilmesi, şartlandırılmas1, depolanması, iletilmesi ve pnömatik iş elemanlarında kullanımı enerji verimliliği yönünden değerlendirilerek örneklerle irdelenmiş ve karşılaştırmalı sonuçlara yer verilmiştir. Sonuçlar incelendiğinde pnömatik sistemlerde enerji tasarruf potansiyelinin büyük bir önem arz ettiği açıkça görülmektedir. Pnömatik sistemlerde enerjinin verimli kullanımıyla ilgili öneriler ve dikkat edilecek hususlar aşağıdaki gibidir.

1. İşletmenin hava ihtiyacı göz önüne alınarak, en düşük spesifik enerji ve yüksüz enerji tüketimine sahip kompresör seçimi yapılmalıdır. Kompresör işletme basıncı mümkün olduğunca düşük tutulmalıdır. İşletme basıncının 7 bar'dan 6 bar'a düşürülmesiyle enerji tüketiminde \%12 tasarruf sağlanabilmektedir.

2. Basınçlı hava hatları tasarlanırken minimum basınç kaybı olacak şekilde doğru boyutlandırma yapılmalıdır. Ring metodu benimsenmeli, yoğuşan su ve yağ zerreciklerinin ayrıştırılabilmesi için drenaj noktaları oluşturarak hattın \%1 oranında eğimli olmasına dikkat edilmelidir.

3. ISO 8573-1:2010 Basınçlı havada kalite standardı uyarınca gerekli hava kalitesi 
belirlenmeli, basınç ve debi kayıplarını önlemek amacıyla hava gerektiği kadar şartlandırılmalıdır.

4. Tasarım sürecinde pnömatik iş elemanları doğru seçilmeli, olması gerekenden fazla itme kuvvetine sahip ürünler enerji tüketiminin artmasına neden olmaktadır. ISO 15552 pnömatik silindirlerde bir alt çapa geçilmesiyle ortalama \%30 oranında daha az hava tüketilmektedir.

5. Tek yönde iş yapan çift etkili pnömatik iş elemanlarında geri dönüş basıncının prosesi etkilemeyecek derecede düşürülmesiyle hava tüketimi azaltılabilmektedir. ISO 1555232 x 125 mm pnömatik silindirin geri dönüş basıncının 6 bardan 2 bara düşürülmesiyle nihai tüketim \%26,5 oranında azalmaktadır.

6. Venturi prensibine göre çalışan vakum ejektörlerinde uygulama için optimum işletme basıncı belirlenmeli, ejektör bu basınçta işletilmelidir. Örnek bir uygulamada işletme basıncının 7 bardan, ekonomik basınç olarak tespit edilen 3,7 bar'a düşürülmesiyle yaklaşık \%35 oranında tasarruf sağlanabilmektedir.

7. Pnömatik sistemlerdeki hava kaçakları ciddi maliyetler oluşturmaktadır. İşletmelerde ultrasonik kaçak dedektörleri kullanılarak periyodik kaçak tespit servisleri uygulanmalıdır. 6 bar basınçta 1 mm'lik delikten dakikada 54 lt hava geçebilmektedir.

8. Açık üfleme işlemlerinde ürün ve proses kalitesinden ödün vermeden eğer uygulanabiliyorsa fan havası tercih edilmelidir. Fan havasının entegre edilemediği durumlarda ise direkt üfleme yerine enerji tasarruf fonksiyonlu nozullar kullanılmalıdır. Hava tabancalarında enerji tasarruf fonksiyonlu ürünlerin kullanımıyla tüketim yaklaşık \%60 oranında azaltılabilmektedir.

9. Verimlilik konusunda yorum yapabilmek için üretilen ve tüketilen hava miktarları debimetreler kullanılarak sürekli olarak takip altına alınmalıdır.

Bu çalışmanın, enerji arzında büyük oranda dışa bağımlı olan ülkemizin sanayi sektöründe enerji yoğunluğunun düşürülmesi ve karbon ayak izinin azaltılması faaliyetlerinde bir rehber niteliği taşıyacağı düşünülmektedir.

\section{KAYNAKÇA}

1. Türkiye Elektrik İletim A.Ş. Genel Müdürlüğü. 2017. "10 yıllık talep tahminleri raporu (2018 - 2027)", Ankara.

2. TMMOB Makinü Mühendisleri Odas1. 2018. “Türkiye'nin Enerji Görünümü 2018”, Oda Raporu, Yayın No MMO/691, Ankara.

3. Frigerio, N., Matta, A. 2015. "Energy-Efficient Control Strategies for Machine Tools With Stochastic Arrivals", IEEE Transactions on Automation Science and Engineering 12 (1): $50-6$. 
4. Uzun, A., Değirmen, M. 2018. "Endüstriyel işletmelerde enerji verimliliği ve enerji yönetimi”, Uluslararası Ekonomik Araştırmalar Dergisi, Cilt:4, Sayı:2.

5. TMMOB Makina Mühendisleri Odası. 2012. "Dünya'da ve Türkiye'de enerji verimliliği”, Oda Raporu, Yayın No MMO/589, Ankara.

6. Enerji İşleri Genel Müdürlüğü. 2018. "Birincil ve nihai enerji yoğunluğu 2010 - 2017”, Ankara.

7. Caro, D. 2018. "Carbon footprint", Reference Module in Earth Systems and Environmental Sciences, Elsevier.

8. Gönençgil, B. 2008. "Doğal süreçler açısından iklim değişikliği ve insan", Çantay Yay1nevi, ISBN: 978-975-9060-50-3.

9. Saidur, R., Rahim, N.A., Hasanuzzaman, M. 2010. “A review on compressed air energy use and energy savings", Renewable and Sustainable Energy Reviews 14, p.1135-1153.

10. Unger, M., Radgen, P. 2017. "Energy efficiency in compressed air systems- a review of energy efficiency potentials, technological development, energy policy actions and future importance" International Conference on Energy Efficiency in Motor Driven Systems, Rome, Italy.

11. Kaya, D., Phelan, P., Chau, D., Sarac, H. I. 2002. "Energy conservation in compressed air systems", International Journal of Energy Research, vol.26,p.837-849.

12. Dindorfa, R. 2012. "Estimating potential energy savings in compressed air systems", Procedia Engineering 39:p.204-211.

13. Emil, M. 2001. "Hava dağıtım sistemleri”, II.Ulusal Hidrolik Pnömatik Kongresi Bildiriler Kitabı, Oda Yayın No: E/2001/278-1, İzmir.

14. Endo, M., Iwamoto, J. 2003."A study of flow field in vacuum ejector driven by air", ASME/JSME 2003 4th Joint Fluids Summer Engineering Conference. 